\title{
Aplikasi Isotop Alam untuk Pendugaan Daerah Resapan Air Mata Air di Kecamatan Cijeruk, Kabupaten Bogor, Jawa Barat
}

\section{Application of Natural Isotopes for Water Catchment Estimation for Springs in Cijeruk District, Bogor Regency, West Java}

\author{
Iffatul Izza Siftianida ${ }^{1}$, Agus Budhie Wijatna ${ }^{1}$ dan Bungkus Pratikno ${ }^{2}$ \\ ${ }^{1}$ Jurusan Teknik Fisika FT UGM \\ Jln. Grafika 2 Yogyakarta 55281 Indonesia \\ e-mail : iffatulizza@yahoo.com \\ ${ }^{2}$ Pusat Aplikasi Isotop dan Radiasi, BATAN \\ Jalan Lebak Bulus Raya No.49 Jakarta 12440 \\ e-mail : bungkus@batan.go.id \\ Diterima 15-08-2016; Diterima dengan revisi 05-09-2016; Disetujui 23-09-2016
}

\begin{abstract}
ABSTRAK
Mata air sebagai sumber air tanah di Kecamatan Cijeruk dimanfaatkan oleh warga sekitar maupun perusahaan air. Pemanfaatan air yang berlebihan menyebabkan terjadinya kekeringan air selama musim kemarau. Perlu adanya konservasi pada daerah resapan air bagi mata air di Kecamatan Cijeruk untuk menjaga ketersediaan air agar mencukupi permintaan air. Penentuan lokasi daerah resapan dan analisis kimia air tanah perlu dilakukan untuk memberi informasi yang diperlukan dalam pelaksanaan konservasi pada daerah resapan mata air. Oleh karena itu penelitian ini bertujuan: (1) menentukan asal usul air tanah, (2) menentukan daerah resapan air mata air, (3) mengetahui fasies air tanah, dan (4) mengetahui kualitas air tanah. Pengambilan sampel dilakukan di Kecamatan Cijeruk, dengan mengambil sampel air tanah yang berasal dari 10 lokasi mata air yang digunakan oleh perusahaan air dan warga pada bulan Mei 2015. Rasio isotop $\delta \mathrm{D}$ dan $\delta^{18} \mathrm{O}$ pada sampel air diukur dengan liquid water stable isotope analyzer LGR DLT-100 untuk menentukan genesis air tanah dan daerah resapan mata air. Analisis hidrokimia untuk mengetahui fasies dan kualitas air tanah. Parameter kimia yang digunakan adalah pH, Daya Hantar Listrik (DHL), Total dissolved Solid (TDS), dan ion mayor. Hasil penelitian menunjukan: (a) mata air berasal dari beberapa sumber yaitu air hujan dan air tanah, (b) daerah resapan CJR01, CJR02, CJR03, dan CJR04 berada pada elevasi 1988 - 2055 m.dpl, (c) daerah resapan CJR06 dan CJR09 pada elevasi 1379 - 1430 m.dpl, (d) daerah resapan mata air CJR07 dan CJR08 pada elevasi 811 - 836 m.dpl, (e) daerah resapan CJR05, dan CJR10 masing - masing berada pada elevasi 1475 mdpl, dan 1932 m.dpl, (f) fasies air tanah tergolong dalam fasies $\mathrm{Mg}-\mathrm{HCO}_{3}$ (magnesium bikarbonat), dan (g) kualitas air tanah merupakan air tawar segar (fresh water).
\end{abstract}

Kata kunci : deuterium, oksigen-18, resapan air, fasies, kualitas, air tanah.

\begin{abstract}
Spring as a source of groundwater in Cijeruk district exploited by local people and water companies. Excessive use of water causes lack of water during dry season. Conservation of recharge areas to maintain the availability of water to supply the water demand. Determination of location recharge areas and chemical analysis of groundwater needs to be done to provide required information to conserve the recharge area. Therefore, this study aims: (1) determine the origin of groundwater, (2) determine recharge area, (3) identify facies of groundwater, and (4) identify the quality of groundwater. Sampling was done in Cijeruk, groundwater samples were collected from 10 locations that were used by water companies and local people in May 2015. The ratio of isotopes $\delta \mathrm{D}$ and $\delta{ }^{18} \mathrm{O}$ in water samples was measured by liquid water stable isotope analyzer LGR DLT -100 to determine the genesis of groundwater and recharge area. Hydrochemical facies analysis to determine groundwater quality. Chemical parameters used are $\mathrm{pH}$, electrical conductivity (EC), Total Dissolved Solid (TDS), and major ions. The results showed: (a) spring origin from several sources suck as rainwater and groundwater, (b) recharge area of CJR01, CJR02, CJR03, and CJR04 located on elevation of 1988 to 2055 m.dpl, (c) recharge area of CJR06 and CJR09 on elevation 1379 - 1430 m.dpl, (d) recharge area of CJR08 and CJR07 on elevation of 811-836 m.dpl, (e) recharge area of CJR05 and CJR10, each located on elevation of 1475 m.dpl, and 1932 m.dpl, (f) the groundwater facies is $\mathrm{Mg}-\mathrm{HCO} 3$ (magnesium bicarbonate), and (g) the quality of groundwater is fresh water.
\end{abstract}

Keywords : deuterium, oxygen-18, recharge area, facies, quality, groundwater. 


\section{PENDAHULUAN}

Kecamatan Cijeruk merupakan salah satu wilayah di Kabupaten Bogor yang memiliki potensi sumber mata air besar. Mata air sebagai sumber air tanah di Kecamatan Cijeruk dimanfaatkan oleh masyarakat maupun perusahaan air untuk bahan baku produksi, kebutuhan rumah tangga dan pertanian.

Pemanfaatan air yang berlebihan mengakibatkan terjadinya kelangkaan air di beberapa daerah. Pada tahun 2011 terjadi kekeringan air selama musim kemarau di wilayah Desa Cijeruk yang berada di kaki Gunung Salak. Hal ini diakibatkan karena adanya eksploitasi sumber mata air di Gunung Salak oleh perusahaan air di Kecamatan Cijeruk [1].

Pengelolaan air di Kecamataan Cijeruk diperlukan, mengingat besarnya potensi sumber mata air yang harus dijaga kelestariannya dengan melakukan konservasi di daerah resapan mata air. Konservasi pada daerah resapan mata air dilakukan untuk menjaga ketersediaan air di mata air mampu mencukupi permintaan air. Penentuan titik lokasi daerah resapan dan analisis kimia air tanah perlu dilakukan untuk memberi informasi yang diperlukan dalam pelaksanaan konservasi pada daerah resapan mata air. Oleh karena itu penelitian ini bertujuan: (1) menentukan asal usul dan genesis air tanah pada mata air, (2) menentukan daerah resapan mata air, (3) mengetahui fasies air tanah pada mata air, dan (4) mengetahui kualitas air tanah pada mata air.

Aplikasi isotop alam merupakan salah satu metode yang digunakan sebagai tinjauan mengenai dinamika air tanah dalam aspek hidrogeologi, khususnya tentang asal usul air tanah. Isotop alam yang digunakan merupakan isotop stabil Deuterium $\left({ }^{2} \mathrm{H}\right.$ atau D ) dan isotop Oksigen-18 $\left({ }^{18} \mathrm{O}\right)$ serta molekul radioisotop Tritium $\left({ }^{3} \mathrm{H}\right)$ dan Karbon-14 $\left({ }^{14} \mathrm{C}\right)$. Isotop Deuterium dan Oksigen-18 digunakan untuk mengetahui asal-usul atau genesa air tanah sedangkan isotop Tritium dan Karbon-14 digunakan sebagai perunut umur air tanah.

Pemanfaatan isotop alam, $\delta \mathrm{D}$ dan $\delta^{18} \mathrm{O}$ telah digunakan dalam penelitian yang dilakukan oleh Agus Budhie Wijatna. Hasil penelitian yang didapat dari penelitian ini adalah persamaan garis merapi meteoric water line yang dapat digunakan sebagai acuan studi hidrologi menggunakan isotop alam. Dari penelitian ini juga didapatkan daerah resapan air tanah di Umbul Wadon yakni pada elevasi $650-1.260$ m.dpl [2].

Penentuan daerah resapan menggunakan aplikasi isotop alam dilakukan oleh Muhammad Daryl Bustaman untuk menentukan daerah resapan dari Tuk Sibedug. Daerah resapan ditentukan dengan melihat kesamaan rasio isotop dari Tuk Sibedug dengan sumber air yang memiliki elevasi lebih tinggi dibandingkan dengan Tuk Sibedug. Nilai komposisi rasio isotop menunjukan bahwa daerah resapan Tuk Sibedug berasal dari sumur Caturharjo yang memiliki elevasi 270 m.dpl [3].

Kualitas air tanah dapat ditentukan oleh tiga sifat utama, yaitu: sifat fisik, kimia dan biologi/bakteriologi. Sifat fisik dan kimia dapat diwakili oleh parameter kesadahan, jumlah garam terlarut (total dissolved solids atau TDS), daya hantar listrik (electric conductance atau DHL), keasaman, dan kandungan ion. Penelitian yang menggunakan parameter fisik dan kimia ini pernah dilakukan oleh Sarath Prasanth dkk. Dari penelitian ini didapatkan bahwa tidak semua sampel air tanah yang diambil layak untuk diminum. Air tanah yang memiliki kandungan $\mathrm{pH}, \mathrm{DHL}$, ion $\mathrm{Ca}^{2+}, \mathrm{Mg}^{2+}, \mathrm{Na}^{+}$, dan $\mathrm{Cl}^{-}$melebihi batas tidak aman untuk diminum. Penelitian ini juga mendapatkan hasil bahwa fasies air tanah yang dominan mengandung $\mathrm{Ca}-\mathrm{Mg}-\mathrm{HCO}_{3}[4]$.

Penentuan lokasi daerah resapan mata air dapat dilakukan dengan menggunakan metode isotop alam, yaitu isotop deuterium $\left({ }^{2} \mathrm{H}\right.$ atau $\left.\mathrm{D}\right)$ dan isotop oksigen-18 $\left({ }^{18} \mathrm{O}\right)$ yang terkandung dalam molekul air $\left(\mathrm{H}_{2} \mathrm{O}\right)$. Analisis kimia air tanah dilakukan untuk mengetahui kualitas dan fasies air tanah. Fasies air tanah merupakan identifikasi jenis air tanah berdasakan perbedaan dan genesa air yang berhubungan dengan sistem dan tempat keterdapatan air tanah. Analisis isotop alam dan hidrokimia dilakukan untuk memberi informasi mengenai asal usul air tanah mata air, lokasi daerah resapan mata air, kualitas dan fasies air tanah.

\section{BAHAN DAN METODE}

Penelitian ini dilaksanakan dalam beberapa tahapan, yaitu tahap penentuan titik mata air, tahap pengambilan sampel dan tahap pengolahan data atau analisis sampel. 


\section{Penentuan titik pengambilan sampel}

Penentuan titik pengambilan sampel berdasarkan mata air - mata air yang digunakan sebagai sumber air warga dan sumber perusahaan air yang berada di Kecamatan Cijeruk, Kabupaten Bogor. Secara hidrologis wilayah Kecamatan Cijeruk pola aliran mengikuti kelerengan dari wilayah barat ke timur dari perbedaan ketinggian.

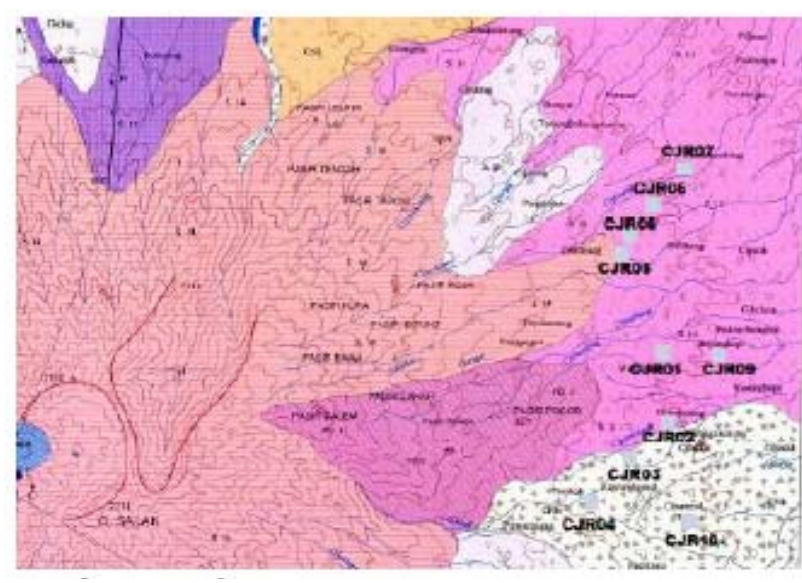

Gambar 1. Lokasi mata air

Tabel 1. Koordinat lokasi dan elevasi mata air

\begin{tabular}{|c|c|c|c|c|}
\hline \multirow[b]{2}{*}{ Kode } & \multirow{2}{*}{$\begin{array}{c}\text { Lokasi } \\
\text { Pengambilan } \\
\text { Sampel }\end{array}$} & \multicolumn{2}{|c|}{ Kordinat Lokasi } & \multirow[b]{2}{*}{$\begin{array}{l}\text { Elevasi } \\
\text { (m.dpl) }\end{array}$} \\
\hline & & $\begin{array}{c}\text { Garis } \\
\text { Lintang }\end{array}$ & Garis Bujur & \\
\hline CJR01 & $\begin{array}{l}\text { Kp. Pasir } \\
\text { Pogor }\end{array}$ & 9258949.28 & 697505.11 & 599 \\
\hline CJR02 & $\begin{array}{l}\text { Kp. Geger } \\
\text { Bitung }\end{array}$ & 9258628.27 & 697676.57 & 573 \\
\hline CJR03 & $\begin{array}{c}\text { Kp. } \\
\text { Cipanengah }\end{array}$ & 9257844.24 & 697156.64 & 612 \\
\hline CJR04 & $\begin{array}{l}\text { Kp. Kawung } \\
\text { Luwuk }\end{array}$ & 9257391.22 & 696293.7 & 719 \\
\hline CJR05 & $\begin{array}{c}\text { Kp. } \\
\text { Cihideung }\end{array}$ & 9259447.05 & 697533.83 & 602 \\
\hline CJR06 & Kp. Balakeng & 9259655.6 & 698111.84 & 559 \\
\hline CJR07 & Kp. Balakeng & 9259954.25 & 698183.37 & 551 \\
\hline CJR08 & $\begin{array}{c}\text { Kp. } \\
\text { Cihideung }\end{array}$ & 9259502.59 & 697527.26 & 604 \\
\hline CJR09 & Bojongkopi & 9259108.31 & 698545.24 & 524 \\
\hline CJR10 & Kp. Cibarayat & 9257367.57 & 698000.91 & 577 \\
\hline
\end{tabular}

\section{Pengambilan sampel}

Pengambilan sampel dilaksanakan pada tanggal 25 Mei 2015. Sebanyak delapan mata air yang dijadikan sampel merupakan mata air yang digunakan sebagai sumber air oleh perusahaan air minum maupun perusahaan air curah di Desa Cijeruk (CJR01, CJR02, CJR03, CJR04, CJR09, dan CJR10) dan Desa Cipelang (CJR06, dan CJR07) sedangkan dua mata air lainnya merupakan sumber air yang digunakan oleh warga Desa Cipelang (CJR05 dan CJR08). Pengambilan sampel disetiap lokasi mata air menggunakan botol dengan volume $60 \mathrm{ml}$ (untuk sampel Deuterium dan Oksigen-18) dan volume $600 \mathrm{ml}$ (untuk analisis kimia).

\section{Pengolahan data}

Analisa isotop : Pengukuran rasio isotop $\delta \mathrm{D}$ dan $\delta^{18} \mathrm{O}$ dalam sampel dilakukan di Laboratorium Kebumian dan Lingkungan, Pusat Aplikasi Teknologi Isotop dan Radiasi (PAIR) BATAN, Jakarta dengan menggunakan peralatan liquid water stable isotope analyzer (LWSIA) Los Gatos Research (LGR) DLT-100. Data hasil pengukuran rasio isotop $\delta \mathrm{D}$ dan $\delta^{18} \mathrm{O}$ sampel air tanah di plot kedalam grafik $\delta \mathrm{D}$ vs. $\quad \delta^{18} \mathrm{O}$. Kemudian grafik tersebut dibandingkan dengan garis meteorik lokal dan global. Posisi rasio isotop $\delta \mathrm{D}$ dan $\delta^{18} \mathrm{O}$ air tanah relatif terhadap garis meteorik lokal dianalisis untuk mendapatkan gambaran genesis sampel air tanah sedangkan penentuan elevasi daerah resapan menggunakan persamaan recharge elevation.

Analisa kimia : Parameter untuk menentukan karakteristik air tanah berupa $\mathrm{pH}$, DHL, TDS, dan ion mayor. Ion mayor tersebut berupa natrium $\left(\mathrm{Na}^{+}\right)$, kalium $\left(\mathrm{K}^{+}\right)$, kalsium $\left(\mathrm{Ca}^{2+}\right)$, magnesium $\left(\mathrm{Mg}^{2+}\right),\left(\mathrm{Cl}^{-}\right)$, sulfat $\left(\mathrm{SO}_{4}{ }^{2+}\right)$, dan bikarbonat $\left(\mathrm{HCO}_{3}^{-}\right)$. Hasil analisa yang didapatkan kemudian diolah dan dianalisis dengan metode diagram trilinier piper. Pembuatan diagram trilinier piper menggunakan software GW_chart.

\section{HASIL DAN PEMBAHASAN}

\section{Analisis komposisi isotop deuterium dan oksigen-18 untuk menentukan genesis air tanah}

Penentuan genesis air tanah menggunakan perbandingan antara isotop berat dengan ringan ditentukan dalam perbedaan rasio isotop yaitu $\mathrm{D} / \mathrm{H}$ dan ${ }^{16} \mathrm{O} /{ }^{18} \mathrm{O}$. Rasio perbandingan antara isotop berat dan isotop ringan dilambangkan dengan $(\delta)$ yang merupakaan perbandingan antara rasio isotop sampel terhadap komposisi isotop dalam air laut (Standard Mean Ocean Water, SMOW). Persamaan 1 menggambarkan komposisi isotop $\delta \mathrm{D}$ (nilai $\delta$ dinyatakan dalam \%o), sedangkan Persamaan 2 menggambarkan komposisi isotop $\delta^{18} \mathrm{O}[5]$ : 


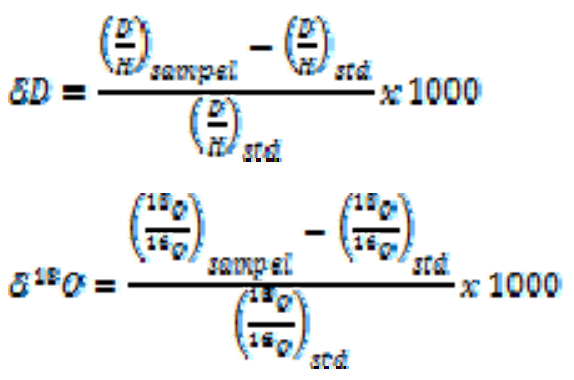

Air dengan deuterium lebih sedikit dibandingkan standar memiliki nilai $\delta \mathrm{D}$ negatif sedangkan air dengan deuterium lebih banyak dibandingkan standar memiliki nilai $\delta \mathrm{D}$ positif. Hal tersebut berlaku pada nilai $\delta^{18} \mathrm{O}[6]$.

Rasio isotop $\delta \mathrm{D}$ dan $\delta^{18} \mathrm{O}$ pada air hujan bervariasi pada fungsi elevasi, jumlah curah hujan dan jarak tertentu. Variasi komposisi isotop dapat dikarakterisasikan dengan menggunakan garis meteoric lokal (LMWL) pada suatu wilayah. sehingga memungkinkan sebagai perunut daerah resapan.

Secara global garis hubungan rerata antara rasio $\delta \mathrm{D}$ dan $\delta^{18} \mathrm{O}$ sebagai fungsi elevasi disebut global meteoric water line (GMWL) dinyatakan dalam Persamaan 3.

$\delta D_{\text {sampel }} \# 8 \cdot \delta^{18} O_{\text {sampel }}+10$

Sedangkan penelitian yang dilakukan di area Gunung Salak, garis meteorik lokal yang didapatkan dari komposisi rasio isotop $\delta^{18} \mathrm{O}$ terhadap komposisi rasio isotop $\delta \mathrm{D}$ yang terkandung dalam air hujan lokal di area penelitian, dan diambil dari air hujan bulanan selama 2 (dua) musim. Dari penelitian tersebut diketahui persamaan garis meteorik lokal area Gunung Salak yaitu Persamaan 4.

$\delta \mathrm{D}=7,4558 \delta^{18} \mathrm{O}+7,92$

Penentuan genesis air tanah dapat dilihat melalui kesamaan nilai $\delta \mathrm{D}$ dan $\delta 180$. Rasio isotop dari sampel kemudian di plot dalam grafik $\delta \mathrm{D}$ vs $\delta^{18} \mathrm{O}$ dan disandingkan dengan garis meteorik lokal dan/atau global. Jika nilai dari $\delta D$ dan $\delta^{18} \mathrm{O}$ dari dua atau lebih titik sampel memiliki nilai yang sama, maka dapat disimpulkan air tanah berasal dari sumber yang sama (memiliki genesis yang sama) atau berada dalam pola aliran yang sama [7].

Pada analisis Deuterium dan Oksigen-18, telah dilakukan 6 kali injeksi untuk setiap sampel. Hasil analisis Deuterium dan Oksigen-18 di rerata dan didapatkan hasil pada Tabel 2.
Tabel 2. Hasil pengukuran analisis Deuterium dan Oksigen - 18.

\begin{tabular}{ccc}
\hline $\begin{array}{c}\text { Kode } \\
\text { Sampel }\end{array}$ & $\delta \mathrm{D}(\%$ SMOW $)$ & $\delta^{18} \mathrm{O}(\%$ SMOW $)$ \\
\hline CJR 01 & $-44.7 \pm 1.2$ & $-8.29 \pm 0.8$ \\
CJR 02 & $-43.7 \pm 1.3$ & $-8.39 \pm 0.9$ \\
CJR 03 & $-44.7 \pm 1.2$ & $-8.50 \pm 1.0$ \\
CJR 04 & $-45.8 \pm 2.1$ & $-8.39 \pm 0.1$ \\
CJR 05 & $-43.3 \pm 2.8$ & $-7.53 \pm 0.8$ \\
CJR 06 & $-46.4 \pm 2.0$ & $-7.37 \pm 0.8$ \\
CJR 07 & $-45.1 \pm 3.3$ & $-6.46 \pm 0.1$ \\
CJR 08 & $-40.8 \pm 5.1$ & $-6.41 \pm 0.7$ \\
CJR 09 & $-45.2 \pm 1.9$ & $-7.45 \pm 0.3$ \\
CJR 10 & $-48.3 \pm 0.7$ & $-8.40 \pm 0.3$ \\
\hline
\end{tabular}

Hasil pengukuran kandungan Deuterium dan Oksigen-18 dalam sampel kemudian di plot dalam grafik $\delta \mathrm{D} \quad v s . \quad \delta^{18} \mathrm{O}$ pada Gambar 2, jikadibandingkan dengan GMWL dan LMWL untuk area Gunung Salak.

Berdasarkan Gambar 2 terdapat 3 kelompok sampel air tanah dengan genesis yang hampir sama. Kelompok 1 terdiri dari dari CJR07 dan CJR08, sedangkan kelompok 2 terdiri dari CJR05, CJR06 dan CJR09. Kelompok 3 terdiri dari CJR01, CJR02, CJR03, CJR04, dan CJR10. Hasil pengukuran kandungan deuterium dan oksigen-18 dalam sampel yang di plot pada Gambar 2 menunjukan bahwa kelompok 1 dan 2 terletak di sekitar garis meteorik lokal.

Hal ini menunjukan bahwa air tanah di kelompok 1 dan 2 merupakan air yang sebagian besar berasal dari air meteorik.

Tabel 3. Nilai rasio isotop kelompok 1.

\begin{tabular}{ccc}
\hline Kode & $\delta \mathrm{D}(\%$ SMOW $)$ & $\delta^{18} \mathrm{O}(\%$ SMOW $)$ \\
Sampel & $-45.1 \pm 3.3$ & $-6.46 \pm 0.1$ \\
CJR 07 & $-40.8 \pm 5.1$ & $-6.41 \pm 0.7$ \\
CJR 08 & & \\
\hline
\end{tabular}

Hasil analisis isotop pada kelompok 1 ditunjukan oleh Tabel 3 menunjukan bahwa titik CJR08 merupakan mata air yang sebagian besar berasal dari air meteorik karena nilai $\delta \mathrm{D}$ dan $\delta 180$ memenuhi persamaan LMWL. Sedangkan titik CJR07 mengalami penyimpangan dari garis meteorik lokal sehingga dapat disimpulkan bahwa CJR07 mengalami evaporasi selama perjalanan dari daerah resapannya. Rasio isotop $\delta \mathrm{D}$ CJR07 dan CJR08 walaupun berbeda namun jika dilihat standar deviasinya, kedua mata air memiliki nilai pada rentang yang sama. Hal ini diperkuat oleh nilai rasio isotop $\delta 180$ yang sama. Oleh karena 

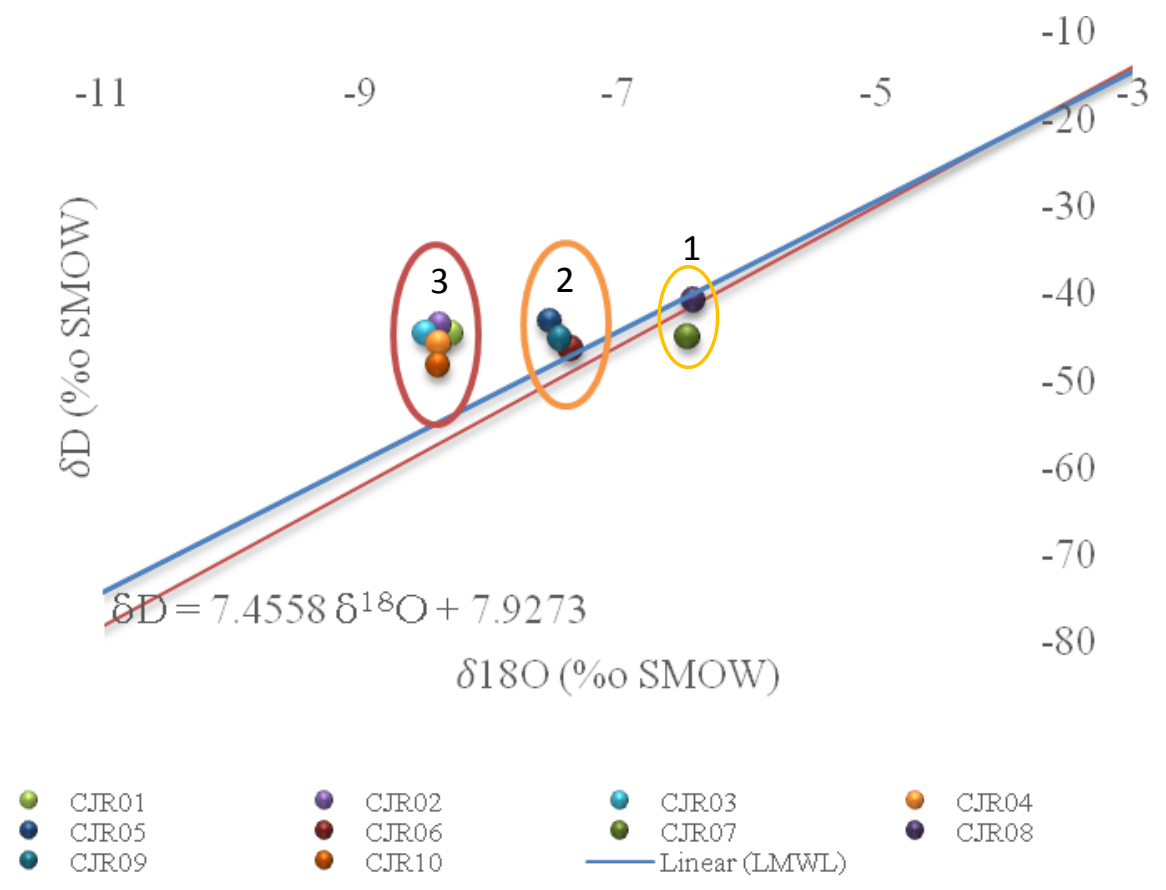

Gambar 2. Grafik hubungan rasio isotop Deuterium dengan Oksigen-18.

itu, CJR07 dan CJR08 memiliki aliran air yang sama maupun asal daerah resapan yang sama. Hasil analisis isotop pada kelompok 2 ditunjukan oleh Tabel 4 menunjukan bahwa titik CJR 06 merupakan mata air yang sebagian besar berasal dari air hujan karena nilai $\delta \mathrm{D}$ dan $\delta 180$ memenuhi persamaan LMWL. Berdasarkan rentang nilai nilai $\delta \mathrm{D}$ dan $\delta 18 \mathrm{O}$ titik CJR 05 , CJR 06, dan CJR 09 pada Tabel 6 dapat disimpulkan bahwa CJR 05, CJR 06 dan CJR 09 mempunyai genesis yang sama namun hanya CJR06 dan CJR09 yang diasumsikan memiliki aliran air yang sama.

Tabel 4. Nilai rasio isotop kelompok 2.

\begin{tabular}{ccc}
\hline Kode Sampel & $\delta \mathrm{D}(\%$ SMOW $)$ & $\delta^{18} \mathrm{O}(\%$ SMOW $)$ \\
\hline CJR 05 & $-43.3 \pm 2.8$ & $-7.53 \pm 0.8$ \\
CJR 06 & $-46.4 \pm 2.0$ & $-7.37 \pm 0.8$ \\
CJR 09 & $-45.2 \pm 1.9$ & $-7.45 \pm 0.3$ \\
\hline
\end{tabular}

Berdasarkan elevasinya, CJR06 yang memiliki ketinggian lebih tinggi daripada CJR09 menunjukan bahwa air mengalir melewati titik CJR06 menuju ke arah CJR09. Sedangkan pada titik CJR05 yang mempunyai nilai $\delta \mathrm{D}$ yang lebih enriched dan memiliki elevasi yang lebih tinggi relatif terhadap CJR06 dan CJR09 menunjukkan bahwa CJR05 meskipun memiliki genesis yang sama namun tidak berada dalam satu aliran dengan CJR06 dan CJR09. Suatu mata air akan memiliki nilai rasio isotop yang lebih depleted untuk elevasi yang lebih tinggi. CJR05 memiliki nilai rasio isotop yang lebih enriched padahal memiliki elevasi yang lebih tinggi, hal ini menunjukkan bahwa CJR05 memiliki aliran air dan daerah resapan yang berbeda dengan CJR06 dan CJR09.

Tabel 5. Nilai rasio isotop kelompok 3.

\begin{tabular}{ccc}
\hline Kode Sampel & $\delta \mathrm{D}(\%$ SMOW) & $\delta^{18} \mathrm{O}(\%$ SMOW) \\
\hline CJR 01 & $-44.7 \pm 1.2$ & $-8.29 \pm 0.8$ \\
CJR 02 & $-43.7 \pm 1.3$ & $-8.39 \pm 0.9$ \\
CJR 03 & $-44.7 \pm 1.2$ & $-8.50 \pm 1.0$ \\
CJR 04 & $-45.8 \pm 2.1$ & $-8.39 \pm 0.1$ \\
CJR 10 & $-48.3 \pm 0.7$ & $-8.40 \pm 0.3$ \\
\hline
\end{tabular}

Hasil analisis isotop pada kelompok 3 yang ditunjukan pada Tabel 5 menunjukan bahwa titik CJR01, CJR02, CJR03, dan CJR04 memiliki rentang nilai $\delta \mathrm{D}$ dan $\delta 18 \mathrm{O}$ yang sama. Sehingga dapat diasumsikan bahwa keempat mata air tersebut dapat berasal dari daerah resapan dan aliran air tanah yang sama. Pada titik CJR10 memiliki nilai $\delta \mathrm{D}$ lebih depleted relatif pada keempat titik mata air lainnya maka dapat diasumsikan bahwa CJR10 tidak memiliki 
kesamaan aliran air dan daerah resapan dengan CJR 01, CJR 02, CJR 03 dan CJR04. Berdasarkan elevasinya, aliran air dari keempat titik tersebut dapat diasumsikan bahwa air mengalir dari CJR04 menuju ke arah CJR03, CJR01, dan CJR02.

\section{Penentuan daerah resapan berdasarkan rasio isotop}

Penentuan daerah resapan air bagi mata air dilakukan berdasarkan hubungan antara komposisi rasio isotop $\delta \mathrm{D}$ atau $\delta^{18} \mathrm{O}$ terhadap elevasi dari lokasi penempatan stasiun curah hujan di area penelitian. Penentuan elevasi daerah resapan menggunakan persamaan recharge elevation yang telah didapatkan dari penelitian sebelumnya.

Dengan memasukkan nilai $\delta \mathrm{D}$ dan $\delta 18 \mathrm{O}$ ke dalam Persamaan 2, mata air-mata air yang disampling didapat data daerah resapan (elevasi recharge) mata air - mata air seperti pada Tabel 6.

Elevasi $=-596,27 \delta 180-3003$

Tabel 6. Hasil pengukuran elevasi daerah resapan air.

$\begin{array}{lccc}\text { Kelompok } & \text { Kode } & \begin{array}{c}\text { Elevasi } \\ \text { (m.dpl) }\end{array} & \text { Elevasi Daerah } \\ \text { Resan (m.dpl) }\end{array}$

\begin{tabular}{cccc}
\hline \multirow{2}{*}{1} & CJR 07 & 551 & 836 \\
& CJR 08 & 604 & 811 \\
\hline \multirow{3}{*}{2} & CJR 05 & 602 & 1475 \\
& CJR 06 & 559 & 1430 \\
& CJR 09 & 524 & 1379 \\
\hline \multirow{3}{*}{3} & CJR 01 & 599 & 2055 \\
& CJR 02 & 573 & 1993 \\
& CJR 03 & 612 & 1991 \\
& CJR 04 & 719 & 1988 \\
\hline
\end{tabular}

Hasil pengukuran elevasi recharge pada kelompok 1 didapatkan bahwa elevasi daerah resapan mata air CJR 07 dan CJR08 yaitu 811 836 m.dpl pada daerah Pasir Koja. Pada kelompok 2, setelah dilihat berdasarkan nilai rasio isotop bahwa CJR 06 dan CJR 09 memiliki genesis yang sama dan aliran air yang sama maka CJR 06 dan CJR 09 dapat diasumsikan berasal dari daerah resapan yang sama. Elevasi daerah resapan mata air CJR 06 dan CJR 09 berada pada rentang 1379 - 1430 mdpl yaitu pada daerah Pasir Kupa, Pasir Dalem, Pasir Rawa, Pasir Lahar dan Pasir Bitung. Sedangkan CJR 05 memiliki daerah resapan matair pada elevasi 1475 m.dpl yaitu pada daerah Pasir Kupa.
Hasil pengukuran elevasi daerah resapan pada kelompok 3, untuk mata air dengan genesis yang sama yaitu CJR 01, CJR 02, CJR 03, dan CJR 04 berasal dari daerah resapan yang memiliki rentang elevasi 1988 - $2055 \mathrm{mdpl}$ pada daerah Pasir Dalem dan sekitar puncak Gunung Salak 1 bagian timur. Sedangkan titik CJR 10 berasal dari daerah resapan yang memiliki elevasi 1932 m.dpl pada daerah Pasir Dalem.

\section{Analisis kimia untuk penentuan kualitas air tanah dan fasies air tanah}

Kandungan hidrokimia pada tiap lapisan akuifer mempunyai ciri tersendiri, tergantung pada batuan yang dilaluinya. Hal ini disebabkan oleh air hujan yang masuk kedalam tanah akan mengalami perkolasi dan interaksi dengan batuan tersebut, dengan adanya peristiwa pelarutan dan pertukaran ion. Hasil analisis kimia dimaksudkan untuk memberikan informasi tambahan atau memperkuat informasi yang telah diperoleh dari hasil analisis deuterium dan oksigen-18 tentang asal - usul air.

Daya hantar listrik (electric conductance) merupakan ukuran kemampuan suatu zat untuk menghantarkan arus listrik dalam temperatur tertentu dengan satuan mikromhos atau mikrosiemen. Kandungan nilai TDS berbanding lurus dengan nilai DHL. Jumlah zat padat terlarut (Total Dissolved Solids / TDS) merupakan jumlah semua mineral terlarut yang tertinggal ketika air teruapkan semuanya atau jumlah konsentrasi garam yang terkandung dalam air [8]. Semakin tinggi nilai DHL suatu air dapat mengindikasikan semakin tinggi jumlah TDS yang terkandung dalam air.

Menurut Schwatrz dan Zang, mineral penyusun batuan akan terlarut dalam air membentuk ion-ion terlarut. Ion - ion tersebut dapat berupa kation maupun anion. Kandungan kation yang terdapat pada hampir semua air di alam adalah natrium $\left(\mathrm{Na}^{+}\right)$, kalium $\left(\mathrm{K}^{+}\right)$, kalsium $\left(\mathrm{Ca}^{2+}\right)$, dan magnesium $\left(\mathrm{Mg}^{2+}\right)$, sedangkan anion antara lain klorida $\left(\mathrm{Cl}^{-}\right)$, sulfat $\left(\mathrm{SO}_{4}{ }^{2-}\right)$, dan bikarbonat $\left(\mathrm{HCO}_{3}^{-}\right)[9]$.

Pada penelitian ini telah dilakukan analisis kimia terhadap sampel untuk mengetahui karakteristik air tanah. Analisis yang dilakukan dapat mengetahui nilai ion mayor yang terlarut dalam sampel air. Nilai ion tersebut dapat menunjukan proses air tanah yang memiliki banyak muatan kimia serta mineral, dan pengaruh mineral dalam air dari batuan dan tanah disekitar 
akuifer. Parameter untuk menentukan karakteristik air tanah berupa $\mathrm{pH}$, DHL, TDS, dan ion mayor. Ion mayor tersebut berupa natrium $\left(\mathrm{Na}^{+}\right)$, kalium $\left(\mathrm{K}^{+}\right)$, kalsium $\left(\mathrm{Ca}^{2+}\right)$, magnesium $\left(\mathrm{Mg}^{2+}\right),\left(\mathrm{Cl}^{-}\right)$, sulfat $\left(\mathrm{SO}_{4}{ }^{2-}\right)$, dan bikarbonat $\left(\mathrm{HCO}_{3}{ }^{-}\right)$.

Hasil laboratorium yang didapatkan kemudian oleh penulis diolah dan dianalisis dengan metode diagram trilinier piper. Kualitas air tanah dapat dicirikan dari daya hantar listrik yang berfungsi sebagai penentu potensi kualitas air tanah untuk air minum. Jumlah ion - ion terlarut semakin tinggi maka semakin rendah kualitas air tanah tersebut. Data hasil analisis kimia untuk parameter DHL dapat dilihat pada Tabel 7. Berdasarkan hasil yang didapatkan nilai DHL sampel mata air berada pada rentang 161 $213.5 \mu \mathrm{S} / \mathrm{cm}$. Berdasarkan klasifikasi air tanah menunjukan bahwa air tanah yang berada di rentang nilai $30-2000 \mu \mathrm{S} / \mathrm{cm}$ merupakan tipe air segar (fresh water) [9]. Oleh karena itu keseluruhan sampel dalam penelitian ini memiliki tipe air segar (fresh water).

Tabel 7. Hasil pengukuran DHL, TDS dan $\mathrm{pH}$.

\begin{tabular}{cccc}
\hline Kode & DHL & TDS & pH \\
\hline CJR01 & 200 & 127.85 & 7.77 \\
CJR02 & 213.5 & 136.84 & 7.76 \\
CJR03 & 165 & 105.88 & 7.72 \\
CJR04 & 161 & 102.88 & 7.77 \\
CJR05 & 202.5 & 129.85 & 7.72 \\
CJR06 & 170 & 108.87 & 7.75 \\
CJR07 & 170 & 108.87 & 7.75 \\
CJR08 & 199.5 & 127.85 & 7.73 \\
CJR09 & 210 & 133.85 & 7.51 \\
CJR10 & 170.5 & 108.87 & 7.52 \\
\hline
\end{tabular}

Kandungan nilai DHL berbanding lurus dengan nilai TDS. Semakin tinggi nilai DHL suatu air dapat mengindikasikan semakin tinggi jumlah TDS yang terkandung dalam air. Hasil analisis TDS dari seluruh sampel menunjukan nilai yang tidak terlalu beragam yaitu sekitar 100 - $140 \mathrm{mg} / \mathrm{L}$. Kandungan nilai TDS yang rendah dapat mengindikasikan bahwa air tanah memiliki waktu kontak yang singkat dengan batuan yang dilewati. Pada pembagian jenis tipe berdasarkan nilai TDS pada rentang nilai kurang dari 1000 $\mathrm{mg} / \mathrm{L}$ merupakan tipe air tawar [9]. Hasil kandungan TDS pada seluruh sampel dapat disimpulkan merupakan tipe air tawar.

Derajat keasaman $(\mathrm{pH})$ didefinisikan sebagai negatif dari logaritma konsentrasi ion hidrogen [9]. Reaksi kimia akan meningkat seiring dengan perubahan temperatur air. Perubahan $\mathrm{pH}$ air bergantung pada jenis endapan akuifernya. Perubahaan $\mathrm{pH}$ air bergantung pada jenis endapan akuifernya. Berdasarkan hasil analisis didapatkan nilai $\mathrm{pH}$ sampel air berada pada rentang 7,51 - 7,77. Nilai $\mathrm{pH}$ tersebut bersifat basa $(\mathrm{pH}>7)$ dan berada di daerah dengan batuan ultramafik. Batuan ultramafik merupakan batuan yang kandungan mineralnya didominasi oleh unsur besi $(\mathrm{Fe})$ dan magnesium $(\mathrm{Mg})$. Fasies air tanah merupakan identifikasi jenis air tanah Pembagian fasies air tanah dapat menggunakan trilinier diagram yaitu diagram piper.

Diagram trilinier piper ini terdiri atas dua buah segitiga yang terletak disebelah kanan bawah dan kiri bawah dari sutau jajaran genjang yang ketiganya mempunyai skala pembacaan 100 . Segitiga kiri untuk pengeplotan kation yang terdiri atas $\mathrm{Ca}^{2+}, \mathrm{Mg}^{2+}$, dan $\mathrm{Na}^{+}$dan $\mathrm{K}^{+}$, sedangkan pada segitiga kanan untuk pengeplotan anion yang terdiri atas $\mathrm{CO}_{3}{ }^{-}+\mathrm{HCO}_{3}{ }^{-}, \mathrm{SO}_{4}{ }^{2-}$, dan $\mathrm{Cl}^{-}$. Pada jajaran genjang titik - titik kation dan anion dari kedua segitiga ditarik ke atas ke dalam jajaran genjang. Berdasarkan letak titik tersebut pada jajaran genjang, hasil pengeplotan kedua segitiga tersebut dipergunakan untuk pengeplotan pada jajaran genjang sehingga dapat diketahui sifat air tanahnya. Berdasarkan perbedaan dan genesa air yang berhubungan dengan sistem dan tempat keterdapatan air tanah [10]. Perbedaan komposisi kimia secara alamiah yang dipengaruhi oleh genetik dari suatu sistem. Fasies hidrokimia dikelompokkan berdasarkan kategori dari komposisi kation dan anion. Dalam sistem aliran yang panjang, air selama pergerakanannya memiliki kecenderungan mengalami perubahan komposisi dan konsetrasi kimia. Parameter ion mayor yang dianalisis digunakan untuk membuat diagram piper. Diagram piper digunakan untuk menentukan fasies air berdasarkan kandungan unsur kimianya. Hasil analisis kimia ion mayor dapat dilihat pada Tabel 8. Hasil kimia ion mayor tersebut diplot pada diagram piper yang ditunjukan pada Gambar 3.

Pada diagram piper tersebut, dapat disimpulkan bahwa seluruh sampel mata air tersebut memiliki kandungan kation dominan yaitu magnesium $\left(\mathrm{Mg}^{2+}\right)$ dan anion dominan yaitu bikarbonat $\left(\mathrm{HCO}_{3}{ }^{-}\right)$. Jajaran genjang diagram piper merupakan penggabungan dua data kation dan anion yang ditunjukan oleh 
Tabel 8. Hasil pengukuran ion mayor.

\begin{tabular}{cccccccc}
\hline Kode & $\begin{array}{c}\mathrm{Ca}^{2+} \\
(\mathrm{mg} / \mathrm{L})\end{array}$ & $\begin{array}{c}\mathrm{Mg}^{2+} \\
(\mathrm{mg} / \mathrm{L})\end{array}$ & $\begin{array}{c}\mathrm{HCO}_{3}{ }^{-} \\
(\mathrm{mg} / \mathrm{L})\end{array}$ & $\begin{array}{c}\mathrm{Na}^{+} \\
(\mathrm{mg} / \mathrm{L})\end{array}$ & $\begin{array}{c}\mathrm{K}^{+} \\
(\mathrm{mg} / \mathrm{L})\end{array}$ & $\begin{array}{c}\mathrm{SO}_{4}{ }^{2-} \\
(\mathrm{mg} / \mathrm{L})\end{array}$ & $\begin{array}{c}\mathrm{Cl}^{-} \\
(\mathrm{mg} / \mathrm{L})\end{array}$ \\
\hline CJR01 & 32 & 35 & 68 & 2,0840 & 2,2626 & 4,96 & 18 \\
CJR02 & 30 & 35 & 52 & 4,7330 & 4,9640 & 3,5 & 22 \\
CJR03 & 16 & 40 & 80 & 5,5960 & 5,9820 & 1,26 & 14 \\
CJR04 & 20 & 44 & 56 & 1,4580 & 1,5820 & 8,96 & 14 \\
CJR05 & 26 & 54 & 64 & 1,1158 & 1,4550 & 7,97 & 16 \\
CJR06 & 24 & 36 & 68 & 7,6730 & 8,9500 & 5,23 & 20 \\
CJR07 & 22 & 31 & 60 & 1,4275 & 2,2490 & 9,21 & 20 \\
CJR08 & 32 & 39 & 64 & 9,1310 & 10,2600 & 5,98 & 16 \\
CJR09 & 22 & 35 & 52 & 2,8030 & 3,1670 & 5,73 & 18 \\
CJR10 & 12 & 43 & 60 & 12,9780 & 13,8310 & 8,22 & 18 \\
\hline
\end{tabular}

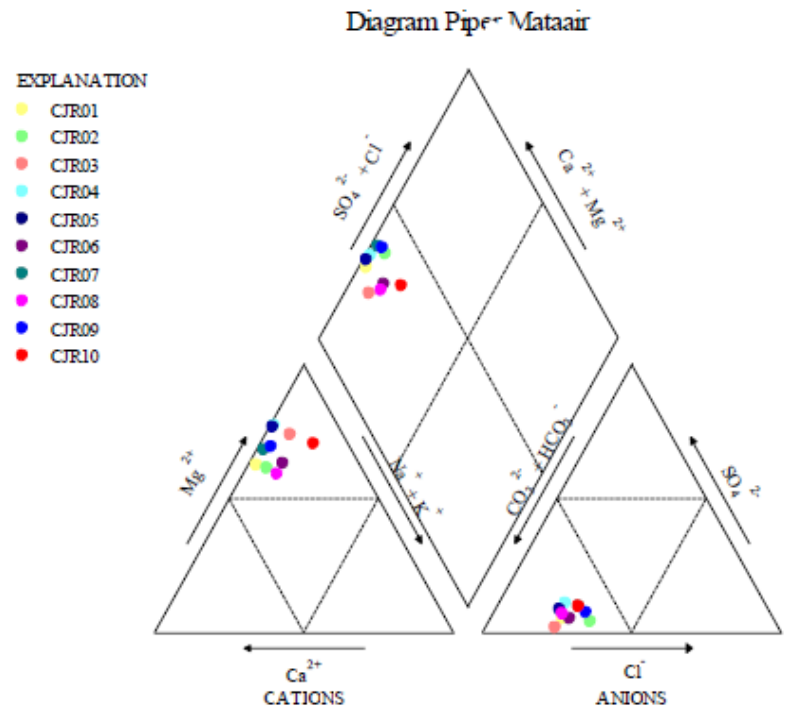

Gambar 3. Diagram piper sampel mata air

dua segitiga yang ada pada diagram piper. Jajaran genjang diagram piper digunakan untuk menentukan tipe air tanah. Berdasarkan diagram piper didapatkan bahwa tipe air tanah dari seluruh sampel ialah magnesium bikarbonat $\left(\mathrm{Mg}-\mathrm{HCO}_{3}\right)$. Air tanah dengan kandungan magnesium bikarbonat menunjukan bahwa komposisi kimiawi yang telah dipengaruhi oleh batuan penyusun akuifernya.

Air tanah pada seluruh sampel mata air memiliki unsur dominan $\mathrm{HCO}_{3}^{-}$, dan $\mathrm{Mg}^{2+}$, nilai DHL berada di rentang 100 hingga $500 \mu \mathrm{S} / \mathrm{cm}$ dan nilai TDS yang rendah, maka dapat disimpulkan bahwa memiliki sistem aliran air tanah lokal. Air tanah jenis ini memiliki komposisi kimia yang mirip dengan air hujan.

\section{KESIMPULAN}

Dari hasil analisis komposisi isotop deuterium dan oksigen-18, dapat ditentukan genesis dan elevasi daerah resapan air bagi mata air di Kecamatan Cijeruk. Berdasarkan genesisnya air tanah dikelompokkan menjadi tiga. Kelompok 1 yang terdiri dari mata air CJR07 dan CJR08 memiliki rentang komposisi $\delta^{18} O=-6,41 \%$ hingga $-6,46 \%$. Kelompok 1 memiliki daerah resapan air yang berada pada elevasi 811 m.dpl 836 m.dpl pada daerah Pasir Koja. Kelompok 2 yang terdiri dari mata air CJR06 dan CJR09 memiliki rentang komposisi $\delta^{18} O=-7,37 \%$ hingga $-7,45 \%$ dengan daerah resapan air pada elevasi 1379 m.dpl - 1430 m.dpl yang berada pada daerah Pasir Kupa, Pasir Dalem, Pasir Rawa, Pasir Lahar dan Pasir Bitung. Kelompok 3 yang terdiri dari mata air CJR01, CJR02, CJR03, dan CJR04 memiliki rentang komposisi $\delta^{18} O=-8,29$ $\%$ hingga $-8,50 \%$ berasal dari daerah resapan air yang berada pada elevasi 1988 m.dpl - 2055 m.dpl pada daerah Pasir Dalem dan sekitar puncak Gunung Salak 1 bagian timur. Pada mata air CJR05 dan CJR10 masing - masing berasal dari daerah resapan air pada elevasi 1475 m.dpl dan 1932 m.dpl.

Berdasarkan hasil DHL yang berada di rentang $161-213,5 \mu S / \mathrm{cm}$ dan hasil TDS dengan nilai $100-140 \mathrm{mg} / \mathrm{L}$, menunjukan bahwa kualitas air tanah pada daerah penelitian yaitu air tawar 
segar (fresh water). Fasies air tanah daerah penelitian secara keseluruhan memiliki anion yang dominan yaitu bikarbonat $\left(\mathrm{HCO}_{3}{ }^{-}\right)$dan kation dominan yaitu magnesium $\left(\mathrm{Mg}^{2+}\right)$. Maka fasies air tanah tergolong dalam fasies $\mathrm{Mg}-\mathrm{HCO}_{3}$ (magnesium bikarbonat).

\section{UCAPAN TERIMA KASIH}

Penulis mengucapkan terima kasih kepada Pusat Aplikasi Isotop dan Radiasi (PAIR) BATAN, yang telah membantu dalam penyusunan karya tulis ini.

\section{DAFTAR PUSTAKA}

1. Pramudya Bagus Setiawan, Penilaian Economic Losses Masyarakat Desa Cijeruk Kabupaten Bogor Akibat Adanya Pemanfaatan Sumber Mata air Oleh Perusahaan Air Minum, IPB, 2002.

2. Agus Budhie Wijatna, Kajian Hidroisotop sebagai Dasar Pertimbangan untuk Penetapan Kawasan Konservasi Air tanah di sekitar Umbul Wadon, Disertasi Sekolah Pascasarjana, Universitas Gadjah Mada, 2014.

3. Muhammad Daryl Bustaman, Aplikasi Isotop Alam untuk Menentukan Daerah Resapan dan Kecepatan Tempuh Aliran Air tanah Menuju Mata air Tuk Sibedug Seyeygan, Kabupaten Sleman, Skripsi Jurusan Teknik Fisika, Fakultas Teknik, Universitas Gadjah Mada, 2011.

4. Sarath Prasanth, N.S. Magesh, K.V. Jitsheshlal, dan N. Chandrasekar, Evaluation of Groundwater Quality and Its Suitability for Drinking and Agricultural Use in The Coastal Stretch of Alappuzha District, Kerala, India, Centre for Geotechnology, Manonmaniam Sundaranar University, 2012.
5. David K. Todd dan Larry W. Mays, Groundwater Hydrology, 3rd Edition, John Wiley Sons, New York, 2004.

6. Payne B.R., Guidebook on Nuclear Techniques in Hydrology, IAEA, Vienna, 1983.

7. Agus B.W., Penentuan Pola Aliran Air tanah Menggunakan Isotop Alam, Laporan Penelitian, Fakultas Teknik Universitas Gadjah Mada, Yogyakarta, 1996. S.M. Metev and V.P. Veiko, Laser Assisted Microtechnology, 2nd ed., R. M. Osgood, Jr., Ed. Berlin, Germany, Springer-Verlag, 1998.

8. Stanley Nelson Davis dan Roger J.M. De Wiest, Hydrogeology, 2nd Edition. John Wiley Sons, New York, 1967.

9. Mandel dan Shiftan, Groundwater Resources Evaluation: Exploration and Exploitation Academic Press, 1981.

10. Freeze, R. Allan and Cherry, John A., Groundwater, New Jersey, 1979.

11. Bungkus Pratikno, Penentuan Zona Resapan Dan Kecepatan Air Tanah Dalam Sistem RECHARGE-DISCHARGE Pada Kasus Lereng Gunung Salak, Bogor, Jawa Barat, Thesis Pasca Sarjana, Fakultas Teknik Geologi, Universitas Padjajaran, 2015.

12. John D. Hem, Study and Interpretation of the Chemical Characteristc of Natural Water, U.S. Geological Survey, Water Supply, United States Government Printing Office, 1985.

13. Brian Fry, Stable Isotope Ecology Springer, New York, 2008.

14. J. Hoefs, Stable Isotop Geochemistry, 6th Edition, Springer-Verlag, Berlin, 2009. 
Jurnal Ilmiah Aplikasi Isotop dan Radiasi

A Scientific Journal for The Applications of Isotopes and Radiation

Vol. 12 No. 2 Desember 2016

ISSN 1907-0322 